\title{
A retrospective analysis of 2713 hospitalized burn patients in a burns center in Turkey
}

\author{
Yavuz Albayrak, M.D., ${ }^{1}$ Ayetullah Temiz, M.D., ${ }^{1}$ Ayşe Albayrak, M.D., ${ }^{2}$ Rıfat Peksöz, M.D., ${ }^{1}$ \\ Fatih Albayrak, M.D., ${ }^{3}$ Yusuf Tanrıkulu, M.D. ${ }^{4}$ \\ ${ }^{1}$ Department of General Surgery, Erzurum Region Training and Research Hospital, Erzurum-Turkey \\ ${ }^{2}$ Department of Infectious Diseases and Clinical Microbiology, Atatürk University Faculty of Medicine, Erzurum-Turkey \\ ${ }^{3}$ Department of Internal Medicine, Faculty of Medicine, Atatürk University Faculty of Medicine, Erzurum-Turkey \\ ${ }^{4}$ Department of General Surgery, KTO Karatay University Faculty of Medicine, Konya-Turkey
}

\begin{abstract}
BACKGROUND: Burn trauma is a significant health problem that has physical, psychological, and economic repercussions on affected patients. The aim of this study was to present epidemiological and demographic characteristics of patients treated over an 8 -year period at a reference burn treatment center located in the northeast of Turkey and serving a population of approximately four million people.
\end{abstract}

METHODS: Each patient's medical record was reviewed, and demographic features, source of burns, place of residence, total body surface area (TBSA), surgical treatment, duration of hospital stay, and mortality rates were analyzed.

RESULTS: The most frequent cause of burn was scalding from hot liquids ( 2013 cases, $74.2 \%)$. Freeze burn was observed in 16 ( $0.6 \%$ ) cases due to climatic conditions of the region where our burn center is located. Grouping based on TBSA revealed that $88.7 \%$ patients had TBSA of $0 \%-15 \%, 8 \%$ patients had TBSA of $15 \%-30 \%$, and $3.3 \%$ patients had TBSA $\geq \% 30$. The most common microorganism was Pseudomonas aeruginosa. A total of 24 patients (0.9\%; 8 males, 16 females) died, including 7 children and 17 adults.

CONCLUSION: Removal of tandirs and replacement with high ovens, restriction of cheese and butter production under primitive circumstances, encouraging cheese and butter production via dairy farm systems, and raising people's awareness through training programs could greatly reduce the number of the burn accidents occurring in this region.

Keywords: Burn injury; freeze burn; scalding.

\section{INTRODUCTION}

Burn trauma is a significant health problem that has physical, psychological, and economic repercussions on affected patients. Physical and psychological consequences of a burn trauma proportionally increase with the extent of the burn area. Burns may have various causes, including fires, scalding agents, chemicals, electricity, and radiation. In developed countries, all of these agents cause burns of variable severity, but late-stage deformities can, in general, be predicted. [1] However, the incidence and causes of burn trauma are di- rectly associated with the economic development of the region in which the burn occurs. For example, the region where our burn center is located within the Erzurum province is at a much lower socioeconomic level than many other regions of Turkey. The cold climate of the region also means prolonged use of heating equipment and hence, an increase in the frequency of burn traumas. The aim of this study was to present epidemiological and demographic characteristics of patients treated over an 8-year period at a reference burn treatment center located in the northeast of Turkey and serving a population of approximately four million people.

Cite this article as: Albayrak Y, Temiz A, Albayrak A, Peksöz R, Albayrak F, Tanrıkulu Y. A retrospective analysis of 2713 hospitalized burn patients in a burns center in Turkey. Ulus Travma Acil Cerrahi Derg 2018;24:25-30

Address for correspondence: Yavuz Albayrak, M.D.

Erzurum Bölge Eğitim ve Araştırma Hastanesi, Genel Cerrahi Kliniği, 25040 Erzurum, Turkey.

Tel: +90 442 - 2422275 E-mail: yavuzalbayrakdr@gmail.com

Ulus Travma Acil Cerrahi Derg 2018;24(I):25-30 DOI: 10.5505/tjtes.2017.82342 Submitted: 15.04.2017 Accepted: 24.05.2017

Copyright 2018 Turkish Association of Trauma and Emergency Surgery 


\section{MATERIALS AND METHODS}

The Erzurum Regional Education and Research Hospital burn treatment center, where this study was conducted, consists of a total of 16 beds, of which four are intensive care beds. The center also houses two medical dressing rooms and operating theaters. This study received approval from the Erzurum Regional Education and Research Hospital ethical committee (dated 21/02/2017 and numbered 02-15). The staff included one surgeon, one practitioner with burn course certification, an anesthesiologist, 10 nurses specialized in burn care, and three technicians. In the 99-month period between September 2008 and December 2016, 9077 patients presented to our hospital with different causes of burns. Of these, 6364 had no indications for inpatient treatment; therefore, they were treated on an outpatient basis. The remaining $27 / 3$ patients underwent inpatient treatment. The criteria for inpatient treatment was affected total body surface area (TBSA) ( $10 \%$ in children and $>15 \%$ in adults); burns on the face, hand, foot, perineum, or major joints; circular burns on extremities; full-thickness burns over $5 \%$ of TBSA; and electrical, chemical, and inhalation burns. Files of $27 \mid 3$ patients who were hospitalized and treated at our center between September 2008 and December 2016 were downloaded from the electronic archive for review. Each patient's medical record was reviewed, and demographic features, source of burns, place of residence, TBSA, surgical treatment, duration of hospital stay, and mortality rates were analyzed. The patients were divided into three groups: those with burns on $0 \%-15 \%$ of TBSA, $15 \%-30 \%$ of TBSA, and $\geq 30 \%$ of TBSA. Causes of burns were divided into seven groups: electrical, scald, contact, chemical, tandir, cold, and flame burns. The severity of the burn was classified as TBSA, which was described as a percentage. ${ }^{[2]}$ The length of hospital stay was classified in days, including the days of admission and discharge. The patients were divided into three groups based on their economic levels: those with a monthly income of $\angle$ USD 400, those with a monthly income of USD 400-800, and those with a monthly income of $>$ USD 800 .

\section{RESULTS}

\section{Age and Sex}

A total of $27 / 3$ acute burn patients were admitted to the Burns Unit of Erzurum Region Training and Research Hospital between September 2008 and December 2016. The median age was $16.3 \pm 19.6$ years, with a range of I month to 87 years. Pediatric patients (0-14 years) accounted for 1755 (64.7\%) and adults accounted for 958 (35.3\%) admissions. There were I 493 (55\%) males and I 220 (45\%) females, for a male to female ratio of I.22:I.

\section{Monthly Admissions}

Our burn center received the highest number of hospitalized and treated patients in July, August, and December, and the lowest number of hospitalized and treated patients in March and April. The monthly admissions data are shown in Fig. I.

\section{Causes of Burns}

The most frequent cause of burn was scalding from hot liquids $(2013$ cases, $74.2 \%)$. The other causes, in order of descending frequency, were flame (327 cases, $12.1 \%$ ); electricity (144 cases, 5.3\%); and contact with hot surfaces/materials, such as a stove or iron (105 cases, 3.9\%), tandir (73 cases, $2.7 \%$ ), and chemical (35 cases, 1.2\%) burns. Freeze burn was observed in $16(0.6 \%)$ cases because of climatic conditions of the region where our burn center is located. There is no inhalation injury in the study. The factors leading to burns are shown in Fig. 2.

\section{Extent of Burns}

The percentage of TBSA ranged from 1\% to $100 \%$, with a mean of $7.50 \% \pm 8.24 \%$. In all patients based on TBSA revealed

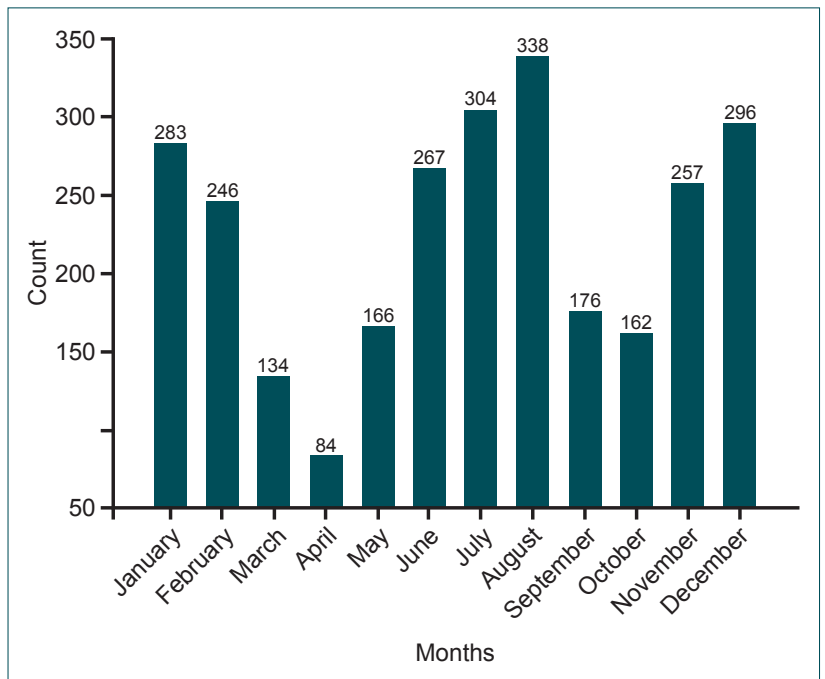

Figure 1. The monthly distribution of the number of patients with burns.

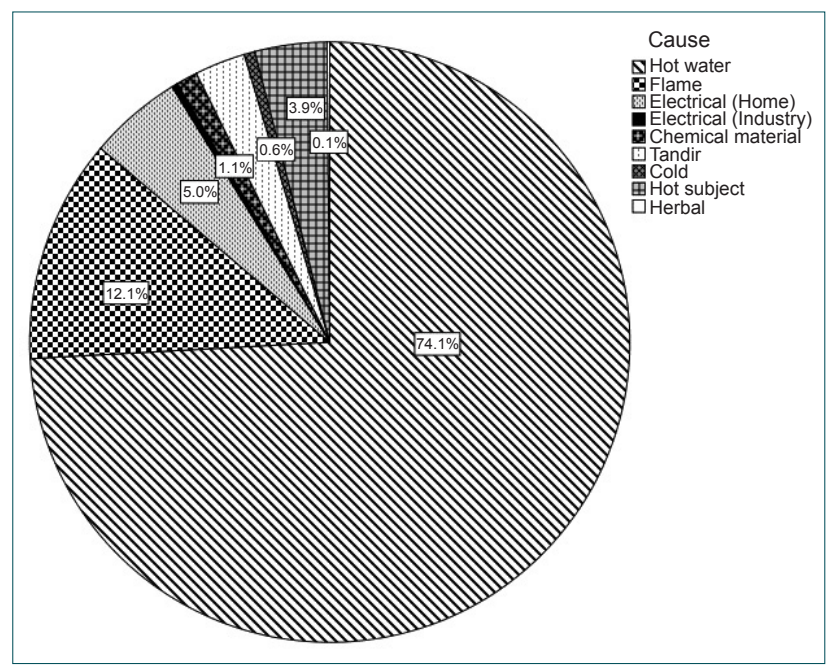

Figure 2. Pie chart representation of the etiological reasons for burns. 
Table I. Microorganisms growing in the burn injury cultures of the patients with burns

\begin{tabular}{lccc}
\hline Causative organisms in patients & $\mathbf{n}$ & $\begin{array}{c}\% \\
\text { (in all patients) }\end{array}$ & $\begin{array}{c}\% \\
\text { (in positive cultures) }\end{array}$ \\
\hline Pseudomonas aeruginosa & 189 & 7 & 16.7 \\
Staphylococcus epidermidis & 160 & 5.9 & 14.1 \\
Methicillin-sensitive Staphylococcus aureus & 95 & 3.5 & 8.4 \\
Methicillin-resistant coagulase-negative staphylococcus & 85 & 3.1 & 7.5 \\
Methicillin-sensitive coagulase-negative staphylococcus & 79 & 2.9 & 7.0 \\
Enterococcus sp. & 53 & 2 & 4.7 \\
Escherichia coli & 44 & 1.6 & 3.9 \\
Acinetobacter sp. & 38 & 1.4 & 3.3 \\
Others & 392 & 14.4 & 34.4 \\
\hline
\end{tabular}

that $88.7 \%, 8 \%$, and $3.3 \%$ patients had TBSA of $0 \%-15 \%, 15 \%-$ $30 \%$, and $>30 \%$, respectively. Among children, I55I (88.4\%), $155(8.8 \%)$, and 49 (2.8\%) had TBSA of $0 \%-15 \%$, I5\%-30\%, and $>30 \%$, respectively. Among adults, 855 (89.2\%), 63 $(6.6 \%)$, and $40(4.2 \%)$ had TBSA of $0 \%-15 \%, 15 \%-30 \%$, and $>30 \%$, respectively. A total of 459 patients (16.9\%) had burns only to the lower extremities, 429 patients (15.8\%) had burns only to the upper extremities, 207 patients (7.6\%) had burn injuries only to the head and neck region, 194 patients $(7.1 \%)$ had burn injuries only to the major joints, 22 patients $(0.8 \%)$ had burn injuries only to the genital region, and 1402 patients (5I.8\%) had burn injuries to multiple regions.

\section{Burn Management}

Treatment of the burn injuries in these 2713 patients included silver sulfadiazine or nitrofurazone in 2345 (86.4\%), net dressing containing chlorhexidine in 841 (31\%), hydrotherapy in $1410(52 \%)$, grafts in $137(5 \%)$, debridement in $85(3.1 \%)$, grafting and debridement in the same session in 48 ( $1.8 \%)$, fasciotomy in $20(0.7 \%)$, and extremity amputation in $16(0.6 \%)$ patients.

Microorganisms growing in the injury cultures of the patients: Among the 2713 patients, II35 patients (4I.8\%) had positive growth in their injury cultures. The most common microorganism was Pseudomonas aeruginosa in 189 patients (16.7\%), followed by Staphylococcus epidermidis in 160 (14.1\%), methicillin-sensitive S. aureus (MSSA) in 95 (8.4\%), methicillin-resistant coagulase-negative staphylococcus in 85 (7.5\%), methicillin-sensitive coagulase-negative staphylococcus in 79 (7.0\%), Enterococcus sp. in 53 (4.7\%), Escherichia coli in 44 (3.9\%), Acinetobacter sp. 38 (3.3\%) and other organisms in 392 (34.5\%). The microorganisms growing in the injury cultures are shown in Table I.

\section{Social and Economic Factors}

A total of 1744 patients (64.3\%) had incomes < American dollars (USD) 400, 947 (34.9\%) had monthly incomes be- tween USD 400 and 800 , and 22 patients $(0.8 \%)$ had incomes $>$ USD 800 .

\section{Lengths of Hospital Stay}

Lengths of hospital stay were I-I I7 days, with a mean stay of $12.9 \pm 10.4$ days. The mean hospital stays were $12.1 \pm 8.8$ days for children and $14.3 \pm 12.6$ days for adults.

The place where the burn event occurred and its judicial side: Places where the burn events occurred were houses (90.4\%), outdoors (6.3\%), workplaces (2.2\%), and vehicles (I.I\%). A total of 2691 patients (99.2\%) suffered from burned by accident, whereas 22 patients $(0.8 \%)$ suffered from burned intentionally.

\section{Post-Burn Interventions}

A total of 570 (21\%) patients were treated with tap water right after the burn. A total of I 46 (5.4\%) patients who came to our hospital had some type of substance applied to their burns [toothpaste, potato, yogurt, molasses (a type of jam made from hot grape juice), or shoe polish].

\section{Patient Discharge from the Clinic and Mortality}

A total of 1645 (60.6\%) patients were discharged upon recovery, whereas 1014 (37.4\%) were discharged without completing their treatment upon the request of the patient or the patient's relatives. Of the patients who were discharged upon their own request, $87.2 \%$ were discharged earlier to take care of their families and $6.7 \%$ of them desired discharge to avoid separation from their spouses. A total of 30 (I.I\%) patients were referred to another center for several reasons. A total of 24 patients $(0.9 \%$; 8 males and 16 females) died, including 7 children and 17 adults. Among the dead patients, 8 had scalding burns, 14 had flash burns, and 2 had tandour burns. Two of the deceased patients had TBSA of $15 \%-30 \%$ and 22 patients had TBSA of $>40 \%$. The patient group which had TBSA of $>40 \%$ had a mortality rate of $57.9 \%$. 


\section{DISCUSSION}

A burn is one of the most severe types of injuries. The causes and demographic features associated with burn injury differ in each country. Our burn center is located in the Erzurum province in the northeast of Turkey, and as the only burn center in this region, it serves a population of 3,217,53I persons in the Erzincan, Bayburt, Gümüşhane, Artvin, Kars, Ardahan, Iğdır, Ağrı, Muş, and Bingöl provinces surrounding Erzurum..$^{[3]}$

The percentage of male patients was higher than that of female patients, in agreement with the results of previous studies, ${ }^{[4-7]}$ although some studies have shown a higher percentage of female patients. ${ }^{[4,8,9]}$ In our study, children constituted the group most affected by burn injury as $64.7 \%$ of our cases were aged $<15$ years, similar to that observed in other studies. $^{[10,11]}$

The highest numbers of patient hospitalizations to our burn center occurred in July, August, December, and January. The climate conditions of the region that our burn center serves necessitates the use of coal burning stoves as a heating equipment in the winter. In the summer, ovens called tandirs (Fig. 3 ) are used in the rural areas. Another reason for the increase in burn cases during summer is falling into milk boilers used to produce cheese and butter. One study reported that the highest number of burn traumas occurred in winter, ${ }^{[2]}$ whereas another study showed that the highest number of burn cases occurred in summer. ${ }^{[13]}$ Our view is that these reported differences are related to differences in the lifestyles, socioeconomic status, and cultural status of the people living in this region.

The lengths of hospital stays for adult patients were longer because their TBSA was higher than that of pediatric patients. This finding agreed with that of a previous study that reported a longer hospital stay for adult patients with high TBSA than for pediatric patients. ${ }^{[14]}$

The most frequent reason for burns in patients admitted to our center was scalding; followed by flash burns. Burns in women and children due to falls into the tandirs used to bake bread were also observed quite frequently in our region. Tandir burns usually led to third degree burns and spontaneous finger and toe amputations, and the patients usually needed grafting surgeries for recovery. ${ }^{[15]}$ Similarly, very severe burns occur because oft children falling into the milk boilers used for butter and cheese production in our region. Our findings are similar to those of our previous studies and many other studies in terms of etiological characteristics. ${ }^{[15-17]}$

Previous studies have shown an association between a high TBSA and increased mortality. ${ }^{[18]}$ The total mortality rate in our study was $0.9 \%$. Previous studies have reported a total mortality rate of $10.5 \%$ and $60 \%$ in the patient group with a TBSA of $>40 \%{ }^{[18]}$ Our patients with a TBSA of $>40 \%$ had a mortality rate of $57.9 \%$, which was in agreement with the results of these previous studies.

Some studies have reported silver sulfadiazine as the most frequently used product for burn treatment. ${ }^{[19,20]}$ We also used silver sulfadiazine for the treatment of burn injuries in our clinic. We observed that net dressings containing chlorhexidine were quite effective in treating the injury of patients with second degree superficial burns, and we recommend the use of this product in patients with second degree superficial burns. We frequently use hydrotherapy in our clinic, particularly in patients with large superficial burn areas and deep burns. We found hydrotherapy to be an effective method for scar elimination. We also observed that the use of creams for chemical debridement was useful in patients when needed.

A total 306 patients (II.3\%) underwent surgical treatment at our center: graft operations were the most frequently used surgical treatment (137 cases). We used graft operation mostly for patients who had experienced flash burns, electrical burns, and burns because of falling into tandours. Debridement operations were the second most common treatment performed at our clinic. We used debridement operations particularly for cases of flash, electrical, and tandour burns because these accidents led to deep burns. Some of our patients underwent repetitive debridement, whereas others underwent a single debridement treatment.

Burn trauma disrupts the integrity of the skin and therefore, microorganisms can easily penetrate the skin and cause infections. Prophylactic antibiotic treatment is routinely usedin our clinic, and we use this treatment in patients with $\geq 30 \%$ TBSA and in patients with additional problems, such as diabetes mellitus and immune sufficiency. $P$. aeruginosa was the microorganism most commonly cultured from the burn injuries in our patients. Patients with positive cultures were evaluated by an infectious disease specialist and treated appropriately. One study reported the presence of $S$. aureus, Pseudomonas $s p$., and Klebsiella sp. as the most common organisms growing in injury cultures. ${ }^{[21]}$ Another study conducted by Akçay et al. in our region reported Pseudomonas sp. (85\%) and Enterobacter aerogenes (I2\%) as the most commonly cultured microorganisms. ${ }^{[22]}$ The results of our study are similar to previous findings.

The socioeconomic status of most (64.3\%) of the patients in our study was represented by a monthly income of $<$ USD 400. Families in the rural parts of our region have many children. However, because majority of these families do not have a good socioeconomic status, they are unable to take care of their children; therefore, burn accidents due to the cultural reasons mentioned (heating, use of tandirs, or milk boilers, etc.) are frequent. In contrast, families with a better socioeconomic status have fewer children and they do not typically live in the rural areas; thus, they experience burn accidents less frequently as they are not exposed to the lead- 
ing factors for burns. Another study also reported that burn accidents tended to occur in the regions with a lower socioeconomic level. ${ }^{[23]}$

The length of hospital stays is related to extensive TBSA, deep burn injury, etiological agents leading to burns, and the patient's age. ${ }^{[2]}$ In our study, the lengths of hospital stays were longer for adults than for pediatric patients, which reflects the higher TBSA of adult patients than that of pediatric patients. Another factor affecting the length of hospital stays was the patient's own request for early discharge without recovery. When patients were asked their reasons for wanting a discharge, they stated that they had to take care of their children or parents at their homes. We also determined that long separations from spouses was another factor that led to requests for early discharge by the patients. Some studies have reported lengths of hospital stay as 13.7-19.5 days, which agree with the lengths of hospital stays determined in our study. ${ }^{[25-27]}$

In summary, the lower socioeconomic level in this region in the northeastern area of Turkey leads to many burn accidents. Our view is that removal of tandirs and replacement with high ovens, restriction of cheese and butter production under primitive circumstances, encouraging cheese and butter production via dairy farm systems, and raising people's awareness through training programs could greatly reduce the number of the burn accidents occurring in this region.

\section{Conflict of interest: None declared.}

\section{REFERENCES}

1. Bekerecioğlu M, Yüksel F, Peker F, Karacaoğlu E, Durak N, Kişlaoğlu E. "Tandir": an old and well known cause of burn injury in the Middle East. Burns 1998;24:654-7. [CrossRef]

2. Lund CC, Browder NC. The estimation of areas of burns. Surg Gynaecol Obstet. 1944;79:352-8.

3. http://www.tuik.gov.tr (Accessed Jul 10, 2017).

4. Lawrence JC. Burns and scalds: aetiology and prevention. In: Settle JAD, editor. Burns management. New York: Churchill Livingstone; 1996. p. $3-25$.

5. Türegün M, Sengezer M, Selmanpakoglu N, Celiköz B, Nişanci M. The last 10 years in a burn centre in Ankara, Turkey: an analysis of 5264 cases. Burns 1997;23:584-90. [CrossRef]

6. Saffle JR, Davis B, Williams P. Recent outcomes in the treatment of burn injury in the United States: a report from the American Burn Association Patient Registry. J Burn Care Rehabil 1995;16:219-32. [CrossRef]

7. De-Souza DA, Marchesan WG, Greene LJ. Epidemiological data and mortality rate of patients hospitalized with burns in Brazil. Burns
1998;24:433-8. [CrossRef]

8. Panjeshahin MR, Lari AR, Talei A, Shamsnia J, Alaghehbandan R. Epidemiology and mortality of burns in the South West of Iran. Burns 2001;27:219-26. [CrossRef]

9. Liu EH, Khatri B, Shakya YM, Richard BM. A 3 year prospective audit of burns patients treated at the Western Regional Hospital of Nepal. Burns 1998;24:129-33. [CrossRef]

10. Kumar P, Chirayil PT, Chittoria R. Ten years epidemiological study of paediatric burns in Manipal, India. Burns 2000;26:261-4. [CrossRef]

11. Mukerji G, Chamania S, Patidar GP, Gupta S. Epidemiology of paediatric burns in Indore, India. Burns 2001;27:33-8. [CrossRef]

12. Hemeda M, Maher A, Mabrouk A. Epidemiology of burns admitted to Ain Shams University Burns Unit, Cairo, Egypt. Burns 2003;29:353-8.

13. Han TH, Kim JH, Yang MS, Han KW, Han SH, Jung JA, et al. A retrospective analysis of 19,157 burns patients: 18-year experience from Hallym Burn Center in Seoul, Korea. Burns 2005;31:465-70. [CrossRef]

14. Ho WS, Ying SY. An epidemiological study of 1063 hospitalized burn patients in a tertiary burns centre in Hong Kong. Burns 2001;27:119-23.

15. Albayrak Y, Cakır C, Albayrak A, Aylu B. A comparison of the morbidity and mortality of tandir burns and non-tandir burns: experience in two centers. Ulus Travma Acil Cerrahi Derg 2011;17:323-8. [CrossRef]

16. Yavuz A, Ayse A, Abdullah Y, Belkiz A. Clinical and demographic features of pediatric burns in the eastern provinces of Turkey. Scand J Trauma Resusc Emerg Med 2011;19:6. [CrossRef]

17. Yastı AÇ, Koç O, Şenel E, Kabalak AA. Hot milk burns in children: a crucial issue among 764 scaldings. Ulus Travma Acil Cerrahi Derg 2011;17:419-22. [CrossRef]

18. Coruh A, Gunay GK, Esmaoglu A. A seven-year burn unit experience in Kayseri, Turkey: 1996 to 2002. J Burn Care Rehabil 2005;26:79-84.

19. Senel E, Yasti AC, Reis E, Doganay M, Karacan CD, Kama NA. Effects on mortality of changing trends in the management of burned children in Turkey: eight years' experience. Burns 2009;35:372-7. [CrossRef]

20. Xin W, Yin Z, Qin Z, Jian L, Tanuseputro P, Gomez M, et al. Characteristics of 1494 pediatric burn patients in Shanghai. Burns 2006;32:613-8.

21. Ramakrishnan KM, Sankar J, Venkatraman J. Profile of pediatric burns Indian experience in a tertiary care burn unit. Burns 2005;31:351-3.

22. Akçay MN, Oztürk G, Aydinli B, Ozoğul B. Tandir burns: a severe cause of burns in rural Turkey. Burns 2008;34:268-70. [CrossRef]

23. Liu Y, Cen Y, Chen JJ, Xu XW, Liu XX. Characteristics of paediatric burns in Sichuan province: epidemiology and prevention. Burns 2012;38:26-31. [CrossRef]

24. Xu JH, Qiu J, Zhou JH, Zhang L, Yuan DF, Dai W, et al. Pediatric burns in military hospitals of China from 2001 to 2007: a retrospective study. Burns 2014;40:1780-8. [CrossRef]

25. Onarheim H, Guttormsen AB, Eriksen E. Burn treated at the Haukeland University Hospital Burn Centre-20 years of experience. Tidsskr Nor Laegeforen 2008;128:1168-71.

26. Chien WC, Pai L, Lin CC, Chen HC. Epidemiology of hospitalized burns patients in Taiwan. Burns 2003;29:582-8. [CrossRef]

27. Haik J, Liran A, Tessone A, Givon A, Orenstein A, Peleg K; Israeli Trauma Group. Burns in Israel: demographic, etiologic and clinical trends, 1997-2003. Isr Med Assoc J 2007;9:659-62. 


\section{ORİJINAL ÇALIŞMA - ÖZET}

\section{Türkiye'deki bir yanık merkezinde yatarak tedavi gören 2713 hastanın geriye dönük analizi} Dr. Yavuz Albayrak, ${ }^{1}$ Dr. Ayetullah Temiz,, ${ }^{1}$ Dr. Ayşe Albayrak, ${ }^{2}$ Dr. Rıfat Peksöz,, ${ }^{1}$ Dr. Fatih Albayrak, ${ }^{3}$ Dr. Yusuf Tanrıkulu ${ }^{4}$

${ }^{1}$ Erzurum Bölge Eğitim ve Araştırma Hastanesi, Genel Cerrahi Kliniği, Erzurum

${ }^{2}$ Atatürk Üniversitesi Tıp Fakültesi, Enfeksiyon Hastalıkları ve Klinik Mikrobiyoloji Anabilim Dalı, Erzurum

${ }^{3}$ Atatürk Üniversitesi Tıp Fakültesi, İç Hastalıkları Anabilim Dalı, Erzurum

${ }^{4}$ KTO Karatay Üniversitesi Tıp Fakültesi, Genel Cerrahi Anabilim Dalı, Konya

AMAÇ: Yanık travması, etkilenen hastalar üzerinde fiziksel, fizyolojik ve ekonomik yansımaları olan ciddi sağlık problemidir. Bu çalışma, Türkiye'nin kuzeydoğusunda bulunan ve yaklaşık dört milyon kişilik bir nüfusa hitap eden, referans bir yanık tedavi merkezinin sekiz yılı aşkın sürede takip ettiği hastaların epidemiyolojik ve demografik özelliklerini sunmayı amaçlamaktadır.

GEREÇ VE YÖNTEM: Hastaların tıbbi dosyalarından, hastaların demografik özellikleri, yanık kaynağı, yanık mahalli, yanık yüzey alanı (YYA), yapılan cerrahi tedavi, hastanede kalıs süresi ve mortalite oranları analiz edildi.

BULGULAR: En sık yanık sebebi sıcak sıvılara bağlı haşlanma yanıkları (20।3 olgu, \%74.2) idi. Yanık merkezimizin bulunduğu bölgenin iklim koşullarına bağlı olarak donma yanığı 16 (\%0.6) olguda gözlemlendi. Yanık yüzey alanına göre hastalar gruplandırıldığında; hastaların \%88.7'si \%0-15, \%8.0'i \% I5-30 ve \%3.3'ü ise \%30'dan fazla YYA'ya sahipti. En fazla izlenen mikroorganizma Pseudomonas aeruginosa idi. Yedisi çocuk olmak üzere toplam 24 (\%0.9) hasta (8 erkek, 16 kadın) öldü.

TARTIŞMA: Tandırların kaldırılması ve yerine yüksekte kurulu olan fırınların oluşturulması, peynir ve tereyağı üretiminin daha gelişmiş şartlarda yapılması ve toplumun yanık konuları hakkında bilgilendirilmesi ile, bu bölgedeki yanık olguları büyük oranda azaltılabilir.

Anahtar sözcükler: Donma yanığı; haşlanma; yanık travması.

Ulus Travma Acil Cerrahi Derg 2018;24(I):25-30 doi: 10.5505/tjtes.2017.82342 